\title{
HUBUNGAN POLA ASUH DENGAN STATUS GIZI BAYI DI KECAMATAN BARUMUN KELURAHAN PASAR SIBUHUAN KABUPATEN PADANG LAWAS TAHUN 2015
}

\author{
Windi Juni Astiti Daulay \\ Akbid Baruna Husada Sibuhuan
}

\begin{abstract}
Parenting is Fulfillment Physical Children. Nutritional status is a state of balance hearts Expression Of Specific Forms embodiment of nutrients hearts Forms Of Specific variables. From January to June 2015 in the District Barumun Padang Lawas, 24 baby bgm (bottom red line). The mother didn't know how to improve the good nutrition for the baby, given a good food and good parenting. This study observational by label cross-sectional design aims to review relationships parenting (parenting eating, self foster health and foster care). The nutritional status of infants in the district Barumun Sibuhuan Market Village Padang Lawas 2015. The population amounted to 1,330 infants (0-12 month), the sample amounted to 93 people. The data collection was done by interviewing using questionnaires and direct observations, the data is processed statistically by the chi square test. The results showed that there is a significant relationship between parenting (parenting Eating, Self foster health and foster care) with the nutritional status of infants in the district of the Village Market Barumun Sibuhuan Padang Lawas District 2015.
\end{abstract}

Keywords : caring pattern, nutrional, status, infant

\section{PENDAHULUAN}

Sejak Dasawarsa 1990-an, kata kunci pembangunan bangsa dinegara berkembang, termasuk di Indonesia adalah Sumber Daya Manusia (SDM). Terciptanya keberhasilan pembangunan suatu bangsa berkaitan erat dengan kualitas SDM yang baik. Dalam menciptakan SDM yang bermutu, perlu ditata sejak dini yaitu dengan memperhatikan kesehatan anak-anak, khususnya anak balita. Derajat kesehatan yang tinggi dalam pembangunan ditujukan untuk mewujudkan manusia yang sehat, cerdas, dan produktif.Salah satu unsur penting dari kesehatan adalah masalah gizi.Gizi sangat penting bagi kehidupan.Kekurangan gizi pada anak dapat menimbulkan beberapa efek negatif seperti lambatnya pertumbuhan badan, rawan terhadap penyakit,menurunnya tingkat kecerdasan, dan terganggunya mental anak. Kekurangan gizi yang serius dapat menyebabkan kematian anak (Soekirman, 2000).

Beberapa penelitian telah membuktikan hubu gan pola asuh dengan status gizi.Sandjaja (2001) meneliti tentang penyimpangan positif (positive deviance)status gizi anak balita.Penelitian ini mengemukakanbahwa ditemukan pada beberapa keluarga dengan sosial ekonomi rendah mempunyai daya adaptasi yang tinggi sehingga mampu tumbuh dan berkembang walaupun menghadapai tekanan ekonomi, sosial dan lingkungan.Faktor yang berperan adalah faktor ibu, pola asuh anak, kesehatan anak dan konsumsi makanan pada balita.

Berdasarkan masalah tersebut maka penelitian ini bermaksud untuk mengetahui hubungan pola asuh makan (pemberian ASI dan MP-ASI) asuh diri (personal higiene, dan lingkungan) dan asuh kesehatan (jenis penyakit, hygiene makanan, dan lama sakit, imunisasi) terhadap status gizi bayi di Kecamatan Barumun Kabupaten Padang Lawas tahun 2015.

\section{PERMASALAHAN}

Berdasarkan uraian latar belakang di atas yang menjadi permasalahan dalam penelitian ini adalah apakah ada hubungan pola asuh (asuh diri, asuh makan dan asuh kesehatan) dengan status gizi bayi di Kecamatan Barumun Kelurahan Psr Sibuhuan Kabupaten Padang Lawas tahun 2015.

\section{TUJUAN UMUM}

Adapun tujuan penelitian ini adalah untuk mengetahui hubungan pola asuh dengan status gizi bayi di Kecamatan Barumun Kelurahan Psr Sibuhuan Kabupaten Padang Lawas tahun 2015.

\section{TUJUAN KHUSUS}

Adapun tujuan khusus dari penelitian ini adalah:

1. Untuk mengetahui hubungan pola asuh makan dengan status gizi bayi di Kecamatan Barumun Kelurahan Pasar Sibuhuan Kabupaten Padang Lawas Tahun 2015.

2. Untuk mengetahui hubungan pola asuh diri dengan status gizi bayi d Kecamatan Barumun Kelurahan 
Pasar Sibuhuan Kabupaten Padang Lawas Tahun 2015.

3. mengetahui hubungan pola asuh kesehatan dengan status gizi bayi di Kecamatan Barumun Kelurahan Pasar Sibuhuan Kabupaten Padang Lawas Tahun 2015.

\section{HIPOTESIS}

Hipotesis pada penelitian ini adalah:

1. Ada hubungan pola asuh makan (jenis makanan, frekuensi makan), dengan status gizi bayi di Kecamatan Barumun Kelurahan Pasar Sibuhuan Kabupaten Padang Lawas Tahun 2015.

2. Ada hubungan pola asuh diri (kebersihan peroran gan, hygiene makanan, hygiene lingkungan) dengan status gizi bayi di Kecamatan Barumun Kelurahan Pasar Sibuhuan Kabupaten Padang Lawas Tahun 2015

3. Ada hubungan pola asuh kesehatan (jenis sakit, frekuensi sakit, lama sakit, imunisasi) dengan status gizi bayi di Kecamatan Barumun Kelurahan Pasar Sibuhuan Kabupaten Padang Lawas Tahun 2015

\section{MANFAAT PENELITIAN}

1. Sebagai bahan masukan bagi Dinas Kesehatan Kabupaten Padang Lawas dan pihak terkait dalam dalam membuat kebijakan penanggulangan masalah pola asuh dengan status gizi bayi.

2. Sebagai bahan masukan dan informasi bagi ibu mengenai pola asuh dan status gizi bayi

3. Sebagai bahan menambah pengetahuan bagi peneliti dan untuk mengetahui masalah pola asuh terhadap status gizi bayi.

\section{TINJAUAN PUSTAKA}

\section{Pola Asuh}

Pola asuh adalah pemenuhan kebutuhan fisik anak. Pola asuh ini termasuk pangan dan gizi, kesehatan dasar, imunisasi, penimbangan, pengobatan, papan/ pemukiman yang layak, hygiene perorangan, sanitasi lingkungan, sandang dan rekreasi (Soekirman, 1999).

Pola asuh yang menjadi bagian dalam sebuah keluarga menjadi semakin menarik dan kompleks, ketika ditemukan fakta bahwa ternyata pola asuh dipengaruhi oleh nilai-nilai yang ada dalam keluarga tersebut, yang dianut atau diyakini oleh orang tua.Sebuah penelitian oleh Natalia dan Iriani (2002) menemukan fakta bahwa dalam pernikahan yang dilangsungkan, terkandung nilai-nilai atau normanorma budaya yang sangat kuat dan luas.Nilai-nilai tersebut terinternalisasi dalam diri masing-masing pasangan.Telaah lintas budaya lebih lanjut juga mendapati adanya pengaruh budaya terhadap pola pengasuhan yang juga berdapak besar pada perkembangan anak (Dayakisni, 2004).

\section{Asuh makan}

Penelitian Guise (2003) menyatakan bahwa ASI mengandung gizi yang baik untuk bayi dan sebagai imunitas untuk melindungi bayi dari infeksi, selain itu juga memberikan keuntungan pada ibu berupa percepatan kembalinya uterus pada posisi semula setelah melahirkan, menghambat ovulasi dan menurunkan risiko kanker payudara, kanker ovarium dan kanker endometrium. Penelitian lain oleh Scariati (1997) menunjukkan bahwa ASI dapat memberikan perlindungan terhadap penyakit diare dan peradangan telinga.

\section{Asuh Diri}

Anwar (2005) mengatakan bahwa asuh diri meliputi perilaku ibu memelihara kebersihan rumah, higiene makanan, kebersihan perseorangan. Pemberian nutrisi tanpa memperhatikan kebersihan akan mangkibatkan infeksi pada bayi, seperti diare.

Hasil penelitian Widodo (2005) mengungkapkan akibat rendahnya sanitasi dan hygiene pada pemberian MP-ASI memungkinkan terjadinya kontaminasi oleh mikroba, sehingga meningkatkan resiko atau infeksi yang lain pada bayi. Sumber infeksi yang lain adalah permainan dan lingkungan bermain yang kotor.

\section{Asuh Kesehatan}

Budi (2006) mengatakan bayi adalah kelompok usia yang rentan terserang penyakit, terkait dengan intraksi dengan sarana dan prasarana di rumah tangga sendiri dan sekelilingnya. Jenis sakit yang dialami, frekuensi sakit, lama sakit, penanganan bayi sakit dan status imunisasi adalah faktor yang mempengaruhi tingkat kesehatan bayi dan status gizi bayi.

Menurut Budi (2006), perilaku ibu dalam menghadapi bayi yang sakit dan pemantauan kesehatan terprogram adalah pola pengasuhan kesehatan yang sangat mempengaruhi tumbuh kembang bayi. Bayi yang mendapatkan imunisasi akan lebih rendah mengalami resiko penyakit. Bayi yang dipantau pertumbuhan di Posyandu melalui kegiatan penimbangan akan lebih dini mendapatkan informasi akan adanya gangguan pertumbuhan. Sakit yang lama, berulang akan mengurangi nafsu makan yang berakibat pada rendahnya asupan gizi.

\section{Status Gizi}

Status gizi adalah ekspresi dari keadaan keseimbangan dalam bentuk tertentu perwujudan dari nutrisi dalam bentuk variabel tertentu, status gizi dapat pula diartikan sebagai gambaran kondisi fisik seseorang sebagai refleksi dari keseimbangan energy yang masuk dan yang dikeluarkan oleh tubuh (Marmi, 2013).

Supariasa (2002) mengatakan bahwa status gizi ditentukan oleh ketersediaan semua zat gizi dalam jumlah dan kombinasi yang cukup serta waktu yang tepat.Dua hal yang penting adalah terpenuhi semua zat gizi yang dibutuhkan tubuh dan faktor-faktor yang menentukan kebutuhan, penyerapan dan penggunaan zat gizi tersebut. 


\section{Kerangka Konsep Penelitian}

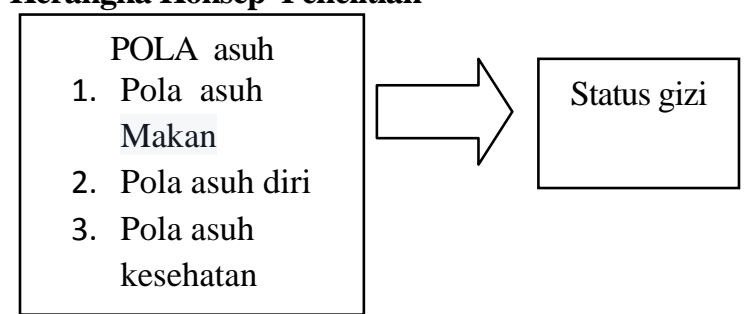

Gambar 2.1. Kerangka Konsep Pola Asuh Terhadap Status Gizi Bayi Keterangan.

\section{JENIS PENELITIAN}

Penelitian ini merupakan penelitian observasional dengan rancangan cross sectional dengan tujuan untuk mengetahui hubungan pola asuh (asuh makan, asuh diri dan asuh kesehatan) dengan status gizi bayi di Kecamatan Barumun Kelurahan Pasar Sibuhuan Kabupaten Padang Lawas tahun 2015.

\section{LOKASI PENELITIAN}

Penelitian ini akan dilakukan di Kecamatan Barumun Kelurahan Pasar Sibuhuan Kabupaten Padang Lawas Tahun 2015.

\section{WAKTU PENELITIAN}

Waktu penelitian ini di mulai dengan pengajuan judul, penelusuran daftar pustaka, konsul pembimbing, merancang kuesioner dan sampai laporan akhir yang di mulai dari bulan mei sampai dengan selesai.

\section{POPULASI}

Populasi dalam penelitian adalah seluruh bayi di Kecamatan Barumun Kelurahan Pasar Sibuhuan Kabupaten Padang Lawas, yaitu 1.330 bayi (0-12 bulan) (Sumber Dinas Kesehatan Kabupaten Padang Lawas).

\section{SAMPEL}

Sampel dalam penelitian ini menggunakan simple random sampling, dengan teknik pengambilan sempel secara lotre tecnicque.Pengambilan sampel menurut (Notoatmodjo, 2005).Sampel adalah sebagian yang diambil dari keseluruhan objek yang diteliti dan dianggap mewakili seluruh populasi (Notoatmodjo, 2005). Sampel terdiri dari bagian populasi terjangkau yang dapat dipergunakan sebagai subjek penelitian melalui sampling.menggunakan rumus:

Besar sampel dalam penelitian ini ditentukan dengan rumus Notoadmodjo (2010), yaitu:

Keterangan:

$$
n=\frac{N}{1+N\left(d^{2}\right)}
$$

n : Besar sampel

$\mathrm{N}$ : Populasi $=1330$ d : Presesi yang ingin dicapai $=10 \%$

Sehingga berdasarkan perhitungan diperoleh jumlah sampel :

$n=\frac{1330}{1+1330}\left(0,1^{2}\right)$

$n=\frac{1330}{1+1330}\left(0,01^{2}\right)$

$n=\frac{1330}{1+13,3}$

$n=\frac{1330}{14,3}=93$ orang

Jumlah sampel ditetapkan menjadi 93 orang.

\section{DATA PRIMER}

Data primer yang diperlukan dalam penelitian ini meliputi: pola asuh (asuh makan, asuh diri dan asuh kesehatan), karakteristik bayi (berat badan lahir, berat badan, umur, jenis kelamin) yang diperoleh melalui wawancara langsung dengan responden menggunakan kuisioner yang diberikan kepada responden.

\section{DATA SEKUNDER}

Data sekunder diperoleh dari kantor Kelurahan Pasar Sibuhuan, yaitu data mengenai demografi penduduk serta gambaran umum mengenai Kelurahan Psr Sibuhuan dan jumlah bayi (0-12 bulan) didasarkan pada hasil pendataan Kantor Kelurahan Pasar Sibuhuan Kabupaten Padang Lawas tahun 2015.

\section{UJI VALIDITAS}

Uji validitas dan reliabilitas terhadap kuisioner ini dilakukan di di Kecamatan Barumun Kelurahan Pasar Sibuhuan Kabupaten Padang Lawas kepada 30 ibu yang memiliki bayi ( $0-12$ bulan).

Uji validitas bertujuan untuk mengetahui sejauh mana suatu ukuran atau nilai yang menunjukkan tingkat kehandalan atau kesahihan suatu alat ukur dengan cara mengukur korelasi antara variabel atau item yang diperoleh dari nilai corrected itemtotal corelation, dengan ketentuan jika nilai $r$ hitung $>r$ tabel maka dinyatakan valid dan sebaliknya, sedangkan reliabilitas data merupakan indeks yang menunjukkan sejauh mana suatu alat ukur dapat dipercaya dan tepat dengan menggunakan metode Cronbach's Alpha, dengan ketentuan jika nilai $\mathrm{r}$ alpha $>\mathrm{r}$ tabel, maka dinyatakan reliabel (Sugiyono, 2004). Nilai r tabel dalam penelitian ini menggunakan critical value of the product moment pada taraf signifikansi 95\%, maka untuk sampel 30 orang yang diuji nilai $r$ tabelnya adalah sebesar 0,361. Hasil analisis validitas dan reliabilitas

\section{UJI RELIABILITAS}

Pernyataan dikatakan reliable, jika jawaban responden terhadap pernyataan (kuesioner) adalah konsisten atau stabil dari waktu ke waktu.Reliabilitas menunjukkan pada suatu pengertian bahwa suatu instrument cukup dapat dipercaya, untuk digunakan sebagai alat pengumpulan data karena instrumen tersebut sudah baik. Instrumen yag sudah dapat 
dipercaya atau reliable akan menghasilkan data yang dapat dipercayai juga. Apabila datanya memang benar dan sesuai dengan kenyataan, maka berapa kali diambil tetap akan sama (arikunto, 2005)

Reliabilitas data merupakan indeks yang menunjukkan sejauh mana suatu alat ukur dapat menunjukkan ketepatan dan dapat dipercayai dengan menggunakan metode cronbach's Alpha, yaitu menganalisis reliabilitas alat ukur dari satu kali pengukuran. Menurut Djemari (2003) dalam Riwidikdo (2008) menyatakan bahwa kuesioner dikatakan reliable jika nilai cronbach's Alpha 0,7.

\section{VARIABEL}

a. Variabel Independen

Variabel independen dalam penelitian ini adalah pola asuh, dimana pola asuh makan, pola asuh diri dan pola asuh kesehatan.

b. Variabel Dependen

Variabel dependen dalam penelitian ini adalah status gizi bayi

\section{METODE PENGUKURAN DATA}

\section{Status Gizi}

Diperoleh melalui penilaian nilai Z-Score dengan indikator berat badan menurut umur (BB/U).Data berat badan diperoleh dan hasil penimbangan di posyandu menggunakan alat penimbangan dacin serta umur dan jenis kelamin bayi dari wawancara dengan ibu. Cara menghitung Z-Score:

\section{METODE ANALISIS DATA}

Analisa data dalam penelitian ini melalui tiga tahapan analisis, yaitu :

a. Analisis Univariat

Analisis data secara univariat dilakukan untuk mendapatkan gambaran distribusi frekuensi variabel dependen, masing-masing variabel independen yang meliputi status gizi bayi (asuh makan, asuh diri, asuh kesehatan).

b. Analisis Bivariat

Analisis bivariat dilakukan untuk menguji ada tidaknya hubungan status gizi bayi (asuh makan, asuh diri, asuh kesehatan) di Kecamatan Barumun Kelurahan Pasar Sibuhuan Kabupaten Padang Lawas diperoleh dengan menggunakan square pada $\alpha=0,05$.

c. Analisis Multivariat

Analisis multivariat ini menggunakan uji regresi logistik ganda pada $\alpha=0,05$, dan yang masuk dalam analisis ini adalah nilai $\mathrm{p}<0,000$ pada analisis bivariat. Analisis dengan uji ini bertujuan untuk menguji hubungan pola asuh (asuh makan, asuh diri, asuh kesehatan) dengan status gizi bayi.Dengan menggunakan tehnik analisis ini dapat diketahui pengaruh dari variabel independen serta mengetahui variabel dominan yang mempengaruhi terhadap status gizi bayi.

\section{DESKRIPSI LOKASI PENELITIAN}

Penelitian ini dilaksanakan di Kecamatan Barumun Kelurahan Pasar Sibuhuan Kabupaten Padang Lawas dengan luas wilayah $\pm 133.78 \mathrm{Ha}$, jumlah penduduk 54.171 jiwa (27.926 perempuan dan 26.245 laki-laki) dan jumlah kepala keluarga 54.171 KK.

\section{HASIL DAN PEMBAHASAN}

\section{Hubungan Pola Asuh Makan Dengan Status Gizi Bayi}

Hasil penelitian menunjukkan bahwa terdapat hubungan antara pola asuh makan dengan status gizi bayi di Kecamatan Barumun Kelurahan Pasar Sibuhuan Kabupaten Padang Lawas Utara yaitu $p=0,000<0,05$. Hal ini dikarenakan antara lain: ibu selalu ada waktu atau selalu mendampingi ketika bayi makan dan ibu dapat membujuk agar bayi mau menghabiskan makanannya.

Hasil penelitian ini sejalan dengan hasil penelitian Sarasani (2005) yang menyatakan bahwa anak yang mempunyai praktek pemberian makan yang baik lebih banyak berstatus gizi baik pula.

Sulistijani (2001), mengemukakan seiring dengan bertambahnya usia anak ragam makanan yang diberikan harus bergizi lengkap dan seimbang yang mana penting untuk menunjang tumbuh kembang dan status gizi anak.

\section{KESIMPULAN}

Berdasarkan tujuan penelitian dan hasil penelitian, maka dapat disimpulkan sebagai berikut:

1. Terdapat hubungan yang signifikan antara pola asuh makan dengan status gizi bayi di Kecamatan Barumun Kelurahan Pasar Sibuhuan Kabupaten Padang Lawas Tahun 2015 dimana nilai $p<0,05$ $(0,000<0,05)$.

2. Tidak terdapat hubungan yang signifikan antara pola asuh diri dengan status gizi bayi di Kecamatan Barumun Kelurahan Pasar Sibuhuan Kabupaten Padang Lawas Tahun 2015 dimana nilai $p>0,05(0,155>0,05)$.

3. Terdapat hubungan yang signifikan antara pola asuh kesehatan dengan status gizi bayi di Kecamatan Barumun Kelurahan Pasar Sibuhuan Kabupaten Padang Lawas Tahun 2015 dimana nilai $p<0,05(0,000<0,05)$.

\section{SARAN}

1. Kepada ibu bayi untuk lebih memperhatikan pola asuh makan, diri dan kesehatan sesuai dengan kebutuhan gizi setiap bayi dan lebih rajin 
berkunjung ke Puskesmas sehingga kondisi berat badan bayi dapat terpantau dengan baik.

2. Kepada petugas kesehatan untuk dapat meningkatkan kegiatan penyuluhan, monitoring dan penilaian status gizi secara berkala dan memberikan bimbingan konsultasi gizi terhadap ibu bayi yang dilakukan secara rutin. Dalam hal ini menyangkut tentang pola asuh makan, diri dan kesehatan.

3. Kepada peneliti selanjutnya diharapkan melakukan penelitian faktor selain pola asuh yang mempengaruhi status gizi bayi yaitu seperti status ekonomi dan sosial budaya.

\section{DAFTAR PUSTAKA}

Anwar, H.M., 2006, Peranan Gizi dan Pola Asuh Dalam Meningkatkan Kualitas Tumbuh Kembang Anak, Jendela Anak Indonesia.

Apriadji, W. H. 1986. Gizi Keluarga. P.T. Penebar Swadaya, Jakarta.

Budi, T.P., 2006, Mengasuh dan Perkembangan Balita, Oriza:Yogyakarta.

Cossio, et all, 2003, Multiple Micronutrient Supplementation During Pregnancy Does Not Lead to Greater Infant Birth Size than does iron-only Supplementation: A Randomized Controlled trial in a Semirural Community in Mexico. Am J.Clin. Nutr.. 77: 720-5

Dayakisni, 2004, Psikologi Sosial, Malang: UMM Press.

Diana, F.M., 2006, Hubungan Pola Asuh Dengan Status Gizi Anak Balita di Kecamatan Kuranji, Kelurahan Pasar Ambacang Kota Padang Tahun 2004, Jurnal Kesehatan Masyarakat, September 2006, I (1).;1923.

Giashudin, M.S., dkk, 2004, Duration of Breast Feeding in Bangladesh, Indian J Med Res, 118:267-272.

Grigsby, D.G., 2005, Malnutrition, Medicine Instant Access to the Minds of Medicine.

Guese, J.M., Palda, V., Westhoff, C., Chan,B.K.S., Helfan, M., \& Lieu,T.A. 2003.

The Effectiveness of Primary Care-Based to Promote Breast feeding: Systematic Evidence Review and Meta-Analysis for the US Preventive Services Task Force. Annual of Family Medicine, 1 (2): 70-78. www.annfammed.org

Heaver, R. A \& Mason, J., 2000, Comparison of Trends In Underweight Children in Indonesia, Philippines, and Thailand, approx, 1975-2000.

Hurlock, B. E., 2002. Perkembangan Anak/Child Development, Terj. Meitasari Tjandrasa, Jakarta : Erlangga.

Indonesian Nutrition Network Forum, 2005, Status Gizi:http//gizi .net/forum/fiewtopik.

Kusumaningsih, P. 2012. Hubungan antara Pemberian MP-ASI dengan StatusGizi pada Bayi Usia 6-12 Bulan di Desa Gogik Kecamtan ungaranBarat. Jawa tengah

Lubis, R., 2008, Hubungan Pola Asuh Ibu Dengan Status Gizi Anak Balita Di Wilayah Kerja Puskesmas
Pantai Cermin Kecamatan Tanjung Pura Kabupaten Langkat Tahun 2008, Skripsi, USU, Medan.

Marmi. 2013. Gizi Dalam Kesehatan Reproduksi. Yogyakarta : Pustaka Pelajar.

Mustafa, 2006, Kajian Status Gizi dan Faktor-faktor yang Mempengaruhi Serta Cara Penanggulangannya Pada Anak Balita Di Kota Banda Aceh Pasca Bencana Gempa Bumi dan Gelombang Tsunami Tahun 2005, Tesis, USU, Medan.

Nadesul, H, 1995. Cara Sehat Mengasuh Anak. Puspa Swara, Jakarta.

Nasution, 2003, Metodologi Penelitian Kuantitatif, Bandung: Tarsito.

Natalia, E., 2006, Pola Asuh dan Pola Penyakit serta Status Gizi Anak Balita pada Keluarga Miskin di desa Durian Dusun IV Kecamatan Pantai Labu Kabupaten Deli Serdang, Skripsi, FKM USU, Medan

Natalia, D., \& Iriani, F. 2002. Penyesuaian Perempuan Non-Batak Terhadap Pasangan Hidupnya Yang Berbudaya

Batak.Jurnal Ilmiah Psikologi.No.VII.27-36.

Notoatmodjo, S., 2010, Metodologi Penelitian Kesehatan, Andi Offset: Yogyakarta.

Nyoman, dkk.,2002,Penilaian Status Gizi, Jakarta: EGC.

Pellitier,.D.L., Franggilow.,E.A., Schroeder, D.G., Habiche., J.P., 1995, The effects Malnutrition On Child Mortality In Developing Country, Bulletin of the World Health Organization. 73 (4:443-48)

Puspitawati, 2013.Sanitasi Lingkungan Yang Tidak Baik Mempengaruhi Status Gizi Pada Balita.Jurnal.STIKES Baptis Kediri. 2013

Rahardjo, dkk, 2012, Pengaruh Pelayanan Kesehatan terhadap Gizi Buruk Anak Usia 6 _ 24 Bulan, Kesmas, Jurnal Kesehatan Masyarakat Nasional Vol. 6, No. 4, Februari 2012.

Rapar, dkk, 2014, Hubungan Pola Asuh Ibu Dengan Status Gizi Balita Di Wilayah Kerja Puskesmas Ranotana Weru Kecamatan Wanea Kota Manado, Skripsi, Universitas Sam Ratulangi, Manado.

Razak, dkk, 2009, Pola Asuh Ibu Sebagai Faktor Risiko Kejadian Kurang Energi Protein (KEP) Pada Anak Balita, Jurnal Vol. 6 No.2, 2009.

Rina, M. Taufik, 2006, Pola Asuh Orang Tua. [Online]. Tersedia: http://www.tabloid_nakita.com. [10 Oktober 2015]

Sandjaja, 2001, Faktor-faktor Positif Deviane

Sarasani.T, 2005.Praktek Pemberian Makan dan Status Gizi Anak Usia 0-24 Bulan ditinjau dari Pekerjaan Ibu, Skripsi, FKM USU, Medan.

Scariati P.D., Strawn L.M.G., Fein S.B, 1997, A Longitudinal Analysis of Infant Morbidity and the Extent of Breast feeding in United States Pediatrics, 99(6): 1-5. http//www.pediatrics.org

Sihombing. E, 2005, Pola Pengasuhan dan Status Gizi Anak Batita ditinjau dari Karakteristik Ibu di 
Kelurahan Sunggal Kecamatan Medan Sunggal, Skripsi, FKM USU, Medan.

Sigelmen, 2002, Life Span Human Development, Fourth Edition, USA: Thomson Wadsworth.

Smith, Haddad, L., 2002, Nutrition and Health: The Ultimate Goals Part 2: Overcoming Child Malnutrition in Developing Countries.

Sediaoetama, 2004,Ilmu Gizi UntukMahasiswa Dan Profesi. Edisi Kelima. Jakarta:Dian Rakyat

Soekirman, 1999, Ilmu Gizi dan Aplikasinya untuk Keluarga dan Masyarakat, Jakarta: Dirjen Dikti Departemen Pendidikan Nasional.

Suhendri, 2009, Faktor-faktor yang Berhubungan Dengan Status Gizi Anak Balita Di Puskesmas Sepatan
Kecamatan Sepatan Kabupaten Tanggerang, Skripsi, UIN Syarif Hidayatullah, Jakarta.

Sukarni, M., 1994.Kesehatan Keluarga dan Lingkungan. Penerbit Kanisius. Yogyakarta.

Sulistijani.2001. Sehat Dengan Menu Berserat. Trubus Agriwidya. Jakarta.

Suiraoka, dkk, 2011, Perbedaan Status Gizi, Pola Pemberian Makan dan Pola Asuh Balita Pada Keluarga Miskin dan Tidak Miskin di Kecamatan Denpasar Utara Kota Denpasar, Jurnal Ilmu Gizi, Volume 2 Nomor 2, Agustus 2011:83-92. 